\title{
ECONOMIC AND AGRONOMIC ANALYSIS OF CONVENTIONAL AND ORGANIC CONCEPT OF CUCUMBER GROWING
}

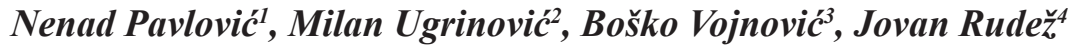

\begin{abstract}
Summary
Contemporary agro-technology enables high and stabile yield of slicing cucumber throughout the whole year. This study deals with total costs of production, yield per surface unit and the main parameters of profitability of producing slicing cucumber in the greenhouses and in the open field in conventional and organic farming system. Growing cucumbers in the greenhouses and in accordance with the principles of organic farming are the main conditions for higher prices in the market. The highest total costs (820.00 EUR/are) but also the highest gain (225.00 EUR/are) was realized in producing slicing cucumber both in the greenhouse in the organic farming system. Financial losses were recorded when growing cucumbers in the open field despite lower costs, both in organic and conventional system of growing: 29.00 EUR/are, i.e. -15.00 EUR/are, respectively. The business rate of profitability and the coefficient of cost-effectiveness were higher in growing cucumber in greenhouses in both concepts of production.
\end{abstract}

Key words: cucumber, profit, business rate of profitability, greenhouse, organic production.

JEL: $Q 16$

\section{Introduction}

Cucumber (Cucumis sativus L.) in Serbia is cultivated in the open field and in greenhouse, at the surface of 8,800 ha, with average yield 6,271.20 kg/ha (FAO, 2012). There are genotypes that are suitable for proceeding and pickling and genotypes for fresh consumption, so-called slicing cucumber (Staub et al., 2008). Pickling cucumbers in Serbia are mostly grown in the

1 Nenad Pavlović, Ph.D, Research Associate, Institute for Vegetable Crops, Karađorđeva Street no. 71, 11420 Smederevska Palanka, Serbia, Phone: +381 26317 170, Email: npavlovicpb@gmail.com

2 Milan Ugrinović, B.Sc, Institute for Vegetable Crops, Karađorđeva Street no. 71, 11420 Smederevska Palanka, Serbia, Phone: +381 26317 170, E-mail: milan.ugrinovic@gmail.com

3 Boško Vojnović, Ph.D., Associate Professor, High School of Agriculture, Vojvode Putnika Street no. 56, 15000 Šabac, Serbia, Phone: +381 15344 580, E-mail: bosko_v@open.telekom.rs

4 Jovan Rudež, M.Sc., Ministry of interior of Republic of Serbia, Sector for Emergency Situations Smederevo, Unit Smederevska Palanka, Ive Bajazita Street no. 14, 11420 Smederevska Palanka, Phone: +381 6680857 00, E-mail: jovan.rudez@gmail.com

EP 2014 (61) 4 (895-902) 
open field, while slicing cucumbers are usually grown in house gardens or in greenhouses. The cucumber is originally from Southern Asia, but now grows on most continents thanks to the new growing technologies. Nowadays it can be grown even in agro-ecological conditions that are not suitable for normal growth and development of this species (Pavlović et al., 2002). Contemporary agro-technical measures enable high yield of slicing cucumber in greenhouses. In temperate climate, in conditions without artificial light it is possible to achieve yields of up to 2,000.00 kg/are (Mao et al., 2003; Mohammadi and Omid, 2010). In organic slicing cucumber production in greenhouse and in Mediterranean climate, yields were up to 1,784.00 kg/are (Tuzel et al., 2007).

In Serbian agro-ecological conditions, slicing cucumber is grown from the nursery or from the direct sowing. Producers can plan time of maturity and in this way produce the most profitably. Direct sowing is performed at the end of April and at the beginning of May when also seedling is planted in the open field. Seedling can be produced during winter months in greenhouses with additional heating. Seed in greenhouses without additional heating can be sown at the beginning of April, while the yield can start in approximately 40 days (Damjanović et al., 2005). In this period the prices of the slicing cucumber are usually higher than at the end of June and the beginning of July, which is the period when cucumber yields in the open filed (STIPS, 2013).

In order to obtain higher prices in the market, the significant point could be the certificated organic production. Organic production implies ecological management of production, improvement of biodiversity, circulation of matter in the nature, microbiological activity in land and environment protection (Zdravković et al., 2010). Due to fears of harmful substances, pesticide residues and heavy metals in vegetables, many consumers are ready to pay from 30 to $80 \%$ more for certified organic products. Due to higher prices of organic products, certified organic production is more profitable despite lower yield and higher costs of production (Engindeniz 2002; Adžić et al., 2010).

The aim of this study was to research the profitability of growing slicing cucumber in greenhouses without additional heating and in the open field in organic and conventional way since these are two actual concepts of growing vegetable.

\section{Material and methods}

In order to research the profitability of slicing cucumber production according to concept of conventional and organic crop production, the trial was set at the research field and in the greenhouse at the Institute for Vegetable Crops, Smederevska Palanka. Standard methods of cucumber growing (both concepts) were applied. Data regarding the prices of material were collected from certified organic producers from Stara Pazova and Belgrade. Data regarding the costs of production and yields from certified organic production were collected by interviewing method (Pavlović et al., 2010; Pavlović, 2014).

The cucumber was grown in greenhouses without additional heating both at the Institute for Vegetable Crops and at the interviewed producers. The cost of greenhouse construction and 
plastic sheeting were calculated by dividing their rates with the predicted lifetime expressed in years (Table 1), (Pavlović, 2014).

Selling prices of slicing cucumber produced in conventional concept of growing were taken from the wholesale market. Sale price of fruits produced in the organic concept were collected by interviewing salesmen from Belgrade and Novi Sad that produce and sell the certified organic vegetable (Pavlović et al., 2010; STIPS, 2013).

Economic analysis was performed by applying method of analytical calculations (Bošnjak and Rodić, 2010) in order to establish the cost price and calculate the basic parameters of profitability of slicing cucumber production. The total cost (EUR), value of production (EUR/are), cost price (EUR/kg), financial results (EUR/are), border of profitability ( $\mathrm{kg} / \mathrm{are})$, business rate of profitability (\%) and coefficient of cost-effectiveness (e) were calculated.

\section{Results and discussion}

Production costs directly affect the profit and manufacturers tend to reduce them as much as possible. For successful production management, managers must always know the costs, as well as their structure and dynamics (Kay et al., 2008). The highest production costs (820.00 EUR/are) were in the organic cucumber production in greenhouses. The costs of conventional production in greenhouses were 529.00 EUR/are. The lowest costs were both in conventional and organic production in the open field 264.00 and $405.00 \mathrm{EUR} / \mathrm{are}$. The total costs of greenhouse production are higher due to the purchase of a greenhouse. During production in greenhouses more human labour is required and specialized machinery costs are increased. Insight into individual costs and the share of these costs in the total production structure are important for decision making, because the economic analysis of production can recognize the dominant group costs, which largely affect the cost of the finished goods (Kanisek et al., 2008).

Cost structure (Table 1) shows that the highest individual cost in both ways of production is the supply of plant material. Quality seedling is a condition of safe and stable production. This cost can be further increased with the organic concept of growing of slicing cucumber, since it is necessary to provide certified organic nursery (Ugrenović et al., 2010). Significant share in the total costs is the protection of plants from pests and diseases. Cucumber is extremely sensitive to plant pathogens so this problem can only be overcome by growing varieties resistant to economically most significant pathogens in Serbia (Mijatović et al., 2001). This would significantly affect the increase the profitability through reducing costs.

During this study, the yield in the greenhouse was $1,450.00 \mathrm{~kg} /$ are in conventional system and $1,100.00 \mathrm{~kg} /$ are in organic, which is in accordance with some authors (Mao et al., 2003; Tuzel et al., 2007; Mohammadi and Omid, 2010). 
Table 1. Total costs of conventional and organic slicing cucumber production in the open field per surface unit (EUR/are)

\begin{tabular}{|c|c|c|c|c|}
\hline \multirow{3}{*}{ Costs } & \multicolumn{2}{|c|}{ Conventional } & \multicolumn{2}{|c|}{ Organic } \\
\hline & Greenhouse & Open field & Greenhouse & Open field \\
\hline & EUR/are & EUR/are & EUR/are & EUR/are \\
\hline Mineral fertilizer & 34.00 & 34.00 & 0.00 & 0.00 \\
\hline Manure & 0.00 & 0.00 & 5.00 & 5.00 \\
\hline The removal of manure & 0.00 & 0.00 & 15.00 & 5.00 \\
\hline Primary treatment & 10.00 & 5.00 & 10.00 & 5.00 \\
\hline Seedling & 150.00 & 80.00 & 200.00 & 100.00 \\
\hline Additional treatment & 5.00 & 2.00 & 5.00 & 2.00 \\
\hline Preparation for planting & 5.00 & 2.00 & 5.00 & 2.00 \\
\hline Greenhouse construction $1 / 10 *$ & 40.00 & 0.00 & 40.00 & 0.00 \\
\hline Plastic foil $1 / 2 *$ & 50.00 & 0.00 & 50.00 & 0.00 \\
\hline Support for the plants & 20.00 & 0.00 & 20.00 & 0.00 \\
\hline Foliar fertilizer & 5.00 & 5.00 & 0.00 & 0.00 \\
\hline Row crop cultivation & 5.00 & 1.00 & 5.00 & 1.00 \\
\hline Irrigation & 10.00 & 5.00 & 10.00 & 5.00 \\
\hline Irrigation system & 80.00 & 40.00 & 80.00 & 40.00 \\
\hline Seasonal labour & 25.00 & 15.00 & 35.00 & 20.00 \\
\hline Approved pesticides & 90.00 & 75.00 & 140.00 & 120.00 \\
\hline Certification costs & 0.00 & 0.00 & 200.00 & 100.00 \\
\hline Total costs & 529.00 & 264.00 & 820.00 & 405.00 \\
\hline
\end{tabular}

Source: According to personal research, Pavlović, 2014.

Note: $* 1 / 10$ - time of depreciation is 10 years; $* 1 / 2$ - time of depreciation is 2 years.

Yield in the open field was $940.00 \mathrm{~kg} /$ are in conventional and $780.00 \mathrm{~kg} /$ are in organic production. Due to climatic conditions and the need for the additional heating, the cucumber production in the open field starts later and the vegetation period and the period of fruiting are shorter, comparing to greenhouse production, which directly influences the total yield of the fruits (Lešić et al., 2004).

Prices of agricultural products are in connection with supply and demand (Babović et al., 2011; Knežević and Popović, 2011). Prices are higher during spring when plants from greenhouses fructify. During summer, when fruits from the open field are yielding, prices are much lower due to a higher supply (STIPS, 2013). Certified organic products, regardless to time of selling are more expensive because the demand is still higher than the supply (Table 2). 
Table 2. Yield per area unit (kg/are), price per unit (EUR/kg), the value of production (EUR/are)

\begin{tabular}{|l|c|c|c|c|}
\hline \multirow{2}{*}{\multicolumn{1}{|c|}{ Indicators }} & \multicolumn{2}{c|}{ Conventional } & \multicolumn{2}{c|}{ Organic } \\
\cline { 2 - 5 } & Greenhouse & Open field & Greenhouse & Open field \\
\hline Yield (kg) & $1,450.00$ & 940.00 & $1,100.00$ & 780.00 \\
\hline Price (EUR/kg) & 0.45 & 0.25 & 0.95 & 0.50 \\
\hline Production value (EUR/are) & 652.50 & 235.00 & $1,045.00$ & 390.00 \\
\hline Financial results (EUR/are) & 123.50 & -29.00 & 325.00 & -15.00 \\
\hline
\end{tabular}

Source: According to personal research, Pavlović, 2014.

The aim of business is to decrease the expenses and increase total value of production and work more profitably in this way. The greatest value of production was achieved in organic cucumber growing in greenhouse (1,045.00 EUR/are). Conventional cucumber growing in greenhouse gained $652.50 \mathrm{EUR} / \mathrm{are}$. In organic growing in the open filed, the value of production was $390.00 \mathrm{EUR} / \mathrm{are}$. The value of production was the lowest in conventional growing in the open filed: $235.00 \mathrm{EUR} / \mathrm{are}$. The total costs in the open field in both concepts of growing exceed the value of production, so the losses were recorded both: - 29.00 and -15.00 EUR/are, respectively (Table 2). According to our research, it is possible to gain profit in organic farming in the open field, if the production is increased. Organic cucumber production in greenhouses was more profitable (225.00 EUR/are) than conventional (123.50 EUR/are).

The attractiveness of vegetable production lies in the rapid turnover of capital, which makes it very interesting for small producers (Pavlović et al., 2010).

Economic efficiency is the indicator of economic management. In our research, the coefficient of economic efficiency was 1.23 and 0.89 for conventional and 1.27 and 0.96 for organic concept (Table 3 ). If the calculated value was higher than 1 the total success of production was higher.

The aim of the economic management is to decrease the costs and to increase total value of production and work more economically efficient.

In our analysis, the conventional growing of slicing cucumber, in greenhouses, on $1,450.00 \mathrm{~kg} /$ are, and with selling price $0.45 \mathrm{EUR} / \mathrm{kg}$, the production value was $652.50 \mathrm{EUR} / \mathrm{kg}$. The costs of this production were 529.00 EUR/are, and the gain was 123.50 EUR/are. Conventional production in the open field was with losses (Table 2). Similar results were calculated by Tuzel et al. (2007) and Mohammadi and Omid (2010). On the other hand, organic growing, in the greenhouses, yielded $1,100.00 \mathrm{~kg} /$ are and had a price at the market $0.95 \mathrm{EUR} / \mathrm{kg}$, which makes the total value of production: 1,045.00 EUR/are (Table 2). Total costs in this way of production were $820.00 \mathrm{EUR} / \mathrm{are}$, and the gain was $225.00 \mathrm{EUR} / \mathrm{are}$. In this concept of growing, the losses were in the open field production (Table 2). 
Table 3. Indicators of profitability of production of conventional and organic slicing cucumber production

\begin{tabular}{|l|c|c|c|c|}
\hline \multirow{2}{*}{\multicolumn{1}{|c|}{ Indicators }} & \multicolumn{2}{c|}{ Conventional } & \multicolumn{2}{c|}{ Organic } \\
\cline { 2 - 5 } & Greenhouse & Open field & Greenhouse & Open field \\
\hline Total costs (EUR/are) & 529.00 & 264.00 & 820.00 & 405.00 \\
\hline Production value (EUR/are) & 652,50 & 235.00 & $1,045.00$ & 390.00 \\
\hline Cost price (EUR/kg) & 0.36 & 0.28 & 0.74 & 0.52 \\
\hline Financial results (EUR/are) & 123.50 & -29.00 & 225.00 & -15.00 \\
\hline Break-even point (kg/are) & $1,175.55$ & $1,056.00$ & 863.20 & 810.00 \\
\hline Rate of return (\%) & 18.90 & -12.30 & 21.50 & -3.85 \\
\hline Coefficient of cost-effectiveness (e) & 1.23 & 0.89 & 1.27 & 0.96 \\
\hline
\end{tabular}

Source: According to personal research, Pavlović, 2014.

Profitability threshold in conventional greenhouse production was $1,175.55 \mathrm{~kg}$. In the organic greenhouse growing, the profitability threshold was $863.02 \mathrm{~kg}$. The difference between yield and profitability threshold, in the first case $(274.45 \mathrm{~kg} / \mathrm{are}$ and $236.80 \mathrm{~kg} / \mathrm{are})$ clearly points the profitability of the ways of production mentioned above.

\section{Conclusion}

Analytical calculation of slicing cucumber growing, in conventional and organic production, proved that it can be profitable, except when growing in the open field in the conventional concept. Relevant parameters of successful production in conventional concept of growing in greenhouses and in the open field are the coefficient of cost-effectiveness 1.23 and 0.89. In organic concept of growing this coefficient was 1.27 and 0.96 . Business rate of profitability for the first concept of growing was $18.90 \%$ and $-12.30 \%$, and in second (organic) $21.50 \%$ and $-3.85 \%$. The highest gain (996 EUR/are), was organic greenhouse production. The only production with losses was conventional open field production. These parameters unequivocally show that producers should turn to organic concept of growing of slicing cucumber.

\section{Acknowledgement}

Financial support for this research was provided by Ministry of Education, Science and Technological Development through grant TR31059.

\section{Literature}

1. Adžić, S., Pavlović, S., Zdravković, J. (2010): Economic justification for vegetable seed concept of sustainable organic production, Economics of Agriculture, IAE Belgrade, vol. 57(SI-2), pp. 20-24.

2. Babović, J., Ignjatijević, S., Đorđević, D. (2011): Supply, demand and elasticity of fish, Ekonomika poljoprivrede, IAE Belgrade, vol. 58, no. 4, pp. 595-608.

3. Bošnjak, D., Rodić, V. (2010): Ekonomska analiza proizvodnje soje u Vojvodini, Ratarstvo i povrtarstvo, Institut za ratarstvo i povrtarstvo, Novi Sad, vol. 47, no. 1, pp. 193-202. 
4. Damjanović, M., Zdravković, J., Zdravković, M., Marković, Ž., Đorđević, R. (2005): Rana i kasna proizvodnja povrća u plastenicima sa dopunskim dogrevanjem. Revija agronomska saznanja, Vojvođansko društvo za poljoprivrednu tehniku, Novi Sad, vol. 15 , no. 3, pp. 51-55.

5. Engindeniz, S. (2002): Economic feasibility of organic greenhouse cucumber production: The case of Menderes, Pakistan journal of biological sciences, vol. 5, no. 3, pp. 367-370, Lahore.

6. FAO (2012): FAO STAT annual report (FAOSTAT Data 2012), available at: http://faostat. fao.org

7. Kanisek, J., Deže, J., Ranogajec, LJ., Miljević, M. (2008): Ekonomska analiza proizvodnje šećerne repe, Poljoprivreda/Agriculture, Savez poljoprivrednih inženjera i tehničara, Beograd, vol. 14, no. 1, pp. 35-40.

8. Kay, R. D., Edwards, W. M., Duffy, P. A. (2008): Farm management, McGraw-Hill, New York.

9. Knežević, M., Popović, R. (2011): Economics of sunflower production in Serbia, Ratarstvo i povrtarstvo, Institut za ratarstvo i povrtarstvo, Novi Sad, vol. 48, no. 1, pp. 213-218.

10.Lešić, R., Borošić, J., Buturac, I., Herak Ćustić, M., Poljak, M., Romić, D. (2004): Povrćarstvo, Zrinski, Čakovec.

11. Mao, X., Liu, M., Wang, X., Liu, C., Hou, Z., Shi, J. (2003): Effects of deficit irrigation on yield and water use of greenhouse grown cucumber in the North China Plain, Agricultural Water Management, vol. 61, pp. 219-228, Amsterdam.

12. Mijatović, M., Ivanović, M., Pavlović, N. (2001): Suzbijanje Pseudoperonospora cubensis prouzrokovača plamenjače krastavca u usevu kornišona, Pesticidi, vol. 16, pp. 253-257, Belgrade.

13. Mohammadi, A., Omid, M. (2010): Economical analysis and relation between energy inputs and yield of greenhouse cucumber production in Iran, Applied Energy, vol. 87, no. 1, pp. 191-196, Amsterdam.

14. Pavlović, N. (2014): Personal survey, Unpublished data, Smederevska Palanka, Serbia.

15. Pavlović, N., Stanković, L., Mijatović, M. (2002): The history of cucumber breeding in Yugoslavia, Cucurbitaceae 2002, pp. 78-81, Naples.

16. Pavlović, N., Ugrinović, M., Zdravković, M. (2010): Economic and agronomic analysis of organic production of tomato and pepper, Economics of Agriculture, IAE Belgrade, vol. 57, no. 2, pp. 153-157.

17. Staub, J. E., Robbins, M. D., Wehner, T. C. (2008): Cucumber. Vegetables, Handbook of plant breeding, Edenbridge Ltd., Enfield.

18. STIPS (2013): Sistem tržišnih informacija poljoprivrede Srbije za 2012. i 2013. Godinu, available at: http://www.stips.minpolj.gov.rs/

19. Tuzel, Y., Gul, A., Karacanci, A., Anac, D., Okur, B., Ongun, A. R., Yoldas, Z., Madanlar, N., Gumus, M., Tuzel, I. H., Engindeniz, S. (2007): Organic cucumber growing in the 
greenhouse, Acta Hort. (ISHS), no. 729, pp. 277-280, Leuven.

20. Ugrenović, V., Filipović, V., Glamočlija, Đ., Jovanović, B. (2010): Organic seed: The production and the certification in the experimental field of the 'Tamiš' Institute, Pančevo, Selekcija i semenarstvo, Društvo selekcionara i semenara Republike Srbije, Belgrade, vol. 16, no. 1, pp. 55-62.

21.Zdravković, J., Pavlović, N., Girek, Z., Zdravković, M., Cvikić, D. (2010): Characteristics important for organic breeding of vegetable crops, Genetika, Društvo genetičara Srbije, Beograd, vol. 42, pp. 223-233.

\title{
EKONOMSKA I AGRONOMSKA ANALIZA GAJENJA KRASTAVCA PO PRINCIPIMA KONVENCIONALNE I ORGANSKE BILJNE PROIZVODNJE
}

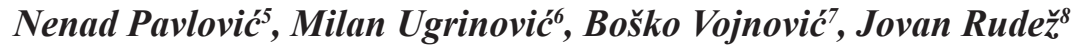

\begin{abstract}
Rezime
Savremenim agrotehničkim merama može se postići visok i stabilan prinos svežeg salatnog krastavca tokom cele godine. U radu su prikazani troškovi proizvodnje, prinos po jedinici površine i osnovni pokazatelji profitabilnosti proizvodnje salatnog krastavca u zaštićenom prostoru $i$ na otvorenom polju, u konvencionalnom i organskom sistemu zemljoradnje. Gajenje u zaštićenom prostoru $i$ u skladu sa principima organske zemljoradnje, proizvođačima omogućava postizanje viših cena na tržištu. Najveći troškovi 820 EUR/a, ali i najveća dobit 225 EUR/are, ostvareni su pri proizvodnji salatnog krastavca u zaštićenom prostoru u organskom sistemu gajenja. Pri gajenju krastavca na otvorenom polju, uprkos nižim troškovima zabeležen je gubitak $i$ u organskom i u konvencionalnom sistemu gajenja, -29 EUR/are odnosno -15 EUR/are respektivno. Vrednosti stope rentabilnosti poslovanja $i$ koeficijenta ekonomičnosti bile su veće pri gajenju krastavca u zaštićenom prostoru kod oba koncepta biljne proizvodnje.
\end{abstract}

Ključne reči: krastavac, dobit, stopa rentabilnosti, zaštićen prostor, organska proizvodnja.

5 Dr Nenad Pavlović, naučni saradnik, Institut za povrtarstvo, Karađorđeva 71, 11420 Smederevska Palanka, Srbija, Telefon: +381 26317 170, E-mail: npavlovicpb@gmail.com

6 Milan Ugrinović, dipl. inž., Institut za povrtarstvo, Karađorđeva 71, 11420 Smederevska Palanka, Srbija, Telefon: +381 26317 170, E-mail: milan.ugrinovic@gmail.com

7 Dr Boško Vojnović, vanredni profesor, Visoka poljoprivredna škola strukovnih studija, Vojvode Putnika 56, 15000 Šabac, Srbija, Telefon: +381 15344 580, E-mail: bosko_v@open.telekom.rs

8 Jovan Rudež, M.Sc., MUP RS, Sektor za vanredne situacije Smederevo, VSJ Smederevska Palanka, Ive Bajazita 14, 11420 Smederevska Palanka, Telefon: +381 6680857 00, E-mail: jovan.rudez@gmail.com 